\section{Animal Liberators Are Not Anti-Science}

\author{
Charles Magel \\ (San Diego, California) \\ Professor of Philosophy Emeritus \\ Moorhead State University \\ Moorhead, Minnesota
}

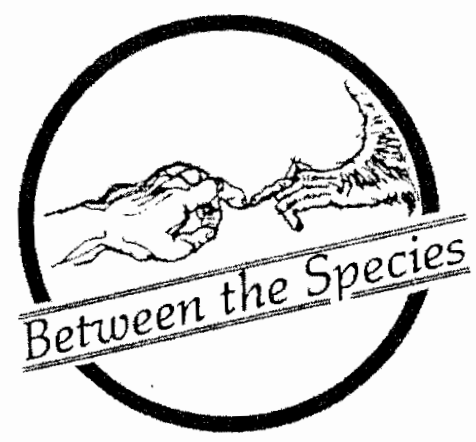

A critical analysis of Animal Liberators: Research and Morality by Susan Sperling (Berkeley: University of California Press, 1988, 247pp.)

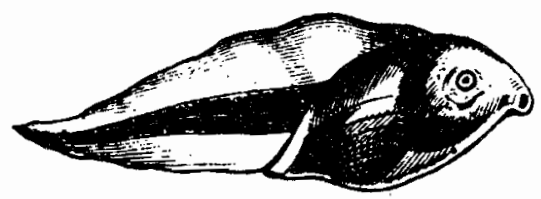

In 1974 the United States Department of Health, Education and Welfare issued a profound set of ethical guidelines for the protection of human subjects participating in experiments. ${ }^{1}$ These guidelines have become standard within the scientific community. Surely there is nothing anti-scientific in the application of these guidelines. The guidelines require an Institutional Review Board approve experiments on humans. The IRB shall determine whether these human subjects will be placed at risk, and if risk is involved make sure:

1. the risks to the subject are so outweighed by the sum of the benefit to the subject and the importance of the knowledge to be gained as to warrant a decision to allow the subject to accept these risks;

2. the rights and welfare of any such subjects will be adequately protected;

3. legally effective informed consent will be obtained by adequate and appropriate methods; and

4. the conduct of the activity will be reviewed at timely intervals.
Special provisions are established for "vulnerables": children, the mentally infirm, the terminally ill, the comatose, etc. Parents or guardians or special advocates must give permission, after insuring that the subject's interests are well protected.

Three philosophical principles ${ }^{2}$ undergird the guidelines:

- the principle of respect

- the principle of beneficence

- the principle of justice

The overall principle is: No human is to participate in an experiment unless there is assurance the subject of the experiment will not be harmed-physically, psychologically, or socially, and unless the subject gives informed consent. The scientific community has accepted this principle. The application of these guidelines is in no way anti-scientific. Scientists do not regard the protection of human subjects in experiments to be inconsistent with academic freedom.

Susan Sperling's Animal Liberators characterizes the modem animal rights movement, and animal rights activists, as being anti-scientific, fearful of science.

I have been an animal liberator-an animal rights activist-for 12 years. Naturally I am interested in some perspective from cultural anthropology, Dr. Sperling's academic discipline. In her book, Sperling mentions the Animal Liberation from Laboratories demonstration

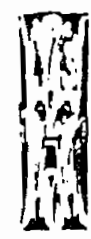

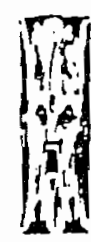


in Los Angeles in 1980. I was on the speakers' platform at that demonstration. Sperling discusses the 1983 demonstrations at three major Primate Research Centers organized by Mobilization for Animals. I was on the speakers' platform at the Primate Research Center at the University of Wisconsin. Sperling discusses maternal separation experiments on langur monkeys. At the University of Wisconsin I was in public debate with psychologist Professor Steven Suomi, who worked with, and co-published with, Harry Harlow on maternal deprivation experiments on rhesus macaque monkeys. I have debated with scientists at the University of Minnesota and North Dakota State University. I spoke at a demonstration at the University of California San Diego Medical School. I served several years on the board of directors of the International Society for Animal Rights. I taught an Animal Rights course at Moorhead State University in Minnesota eight years. Each time, my class was visited by the Chair of the Biology Department, by the Chair of the Psychology Department, and by a representative of the Minnesota Farm Burcau.

I have a deep respect for science. In graduate studies at the University of Minnesota I studied philosophy of science with philosophers of international reputation. I have taught philosophy of science. My life style is based on an attempt to get off the backs of animals to the greatest extent possible. So naturally, I looked forward to learning how a cultural anthropologist would view us animal rights activists.

Let me list some characterizations of us activists, and of the animal rights movement, as viewed by Sperling. Sperling uses the terms "animal liberators" and "animal rights activists" interchangeably. Sperling says, in effect:

1. Your animal rights movement is similar to a charismatic cult (pp. 19, 194);

2. The concept of the millenium (suggestive of millenarian sects and cults in Medieval times) is an important theme in your animal rights ideology (pp. 17, 194, 196-8). (Sperling always uses the term "ideology" in referring to thought-patterns in the animal rights movement. She does not define "ideology." One meaning of "ideology" has the connotation of intentional propagandizing or distortion of facts. She never uses the term "ideology" when discussing the thought-patterns of the lobby groups promoting animal experimen- tation-for example, the California Biomedical Research Association (pp. 18, 19). In that context Sperling uses the terms "hyperrational values" and "hyperrational empiricism" (p. 196). It would be helpful to have a definition of "hyperrational values," or at least some examples.)

3. You animal rights activists think that the use of animals by science must be ended so that human harmony with nature can once again be restored (p. 196);

4. Many of you animal liberators fear an ecological apocalypse, unless animal experiments are stopped by scientists (p. 99);

5. You animal rights activists perceive scientists to be morally corrupt, greedy, and cruel (p. 20);

6. You animal liberators contend that the cessation of animal experimentation is of paramount importance in solving the nuclear crisis (p. 83);

7. Most of you animal rights activists are female, typically in your thirties; but the age range is broad enough to include "a fair number of gray heads" (p. 85);

8. You animal liberators regard science as dangerous (p. 95);

9. You animal rights activists view science as an agent of the destruction of nature. You view scientists and technicians as the institutional representatives of a materialistic society which seeks total domination over the world of nature (p. 97);

10. You animal liberators think the profit motive is the ultimate cause of animal experimentation (p. 97);

11. You animal rights activists regard biomedicine as dangerous and uncaring (p. 98);

12. You animal liberators believe the redemption of society literally depends on the abolition of the use of animals in science (p. 194);

13. As is typical of charismatic cults, many of you animal rights activists are alienated from modem scientific culture, and feel powerless and disenfranchised (p. 195);

14. Unlike the Medieval millenarian charismatic cults which had charismatic prophets, you animal rights 
activists do not have a prophet. Each one of you serves as your own prophet (pp. 196, 198);

15. You animal rights activists tend to regard scientists as "left brainers," exemplifying the linear and "cold" intellectuality of science. You cultists prefer "right brainers," exemplifying intuitive, emotional, "warm" qualities (p. 136);

16. Those of you animal liberators who are radical feminists are alarmed by the connection between the male domination of women (especially in Western medicine) and the harmful experiments on innocent animals by patriarchal scientists (pp. $141,143,148$ );

17. Many of you animal rights activists are holistic health adherents, fearful of scientific incursions disturbing the healthy, harmonious fit of your bodies into the harmonious order of nature. You think organ transplants from animals disrupt this natural harmony (p. 153). You view the production of drugs, medicines, and chemical additives in your food, as technological pollution of both your bodies and of nature (p. 202);

18. Many of you animal liberators, on your first reading of Peter Singer's Animal Liberation, experience something like a revelation, a conversion, changing your whole life (p. 150);

19. Many of you animal rights activists are converted to philosophies of personal revelation - to "popular mystical, transcendental, Eastern Philosophies," like Buddhism, for example. You tend to feel that humans and animals and plants and the entire earth are one mystical being. And you are terrified by the technological incursions of modern science (pp. 150,151 );

20. There is some resemblance between the horror you animal liberators experience when scientists experiment on animals, and the horror of witchcraft when corrupt witches attack innocent victims. This nightmarish resemblance between animal experimentation and witchcraft may partly explain why many of you animal liberators cannot sleep properly, and even some of you are suicidal (pp. 154-5).

So now I have the cultural anthropological perspective on what I have been doing the past 12 years.
I must admit that Dr. Sperling's analysis has put me into a state of shock. I'm surprised Moorhead State University did not fire me the day I joined the animal rights movement.

What are we to make of this nonsense? I suggest that the import of this nonsense can be condensed into one sentence: You animal liberators are an irrational, emotional, alienated cult of fanatical zealots who are overwhelmed by rational science and modern technological society.

If Sperling should tire of teaching I know where she could immediately quadruple her income. The American Medical Association ${ }^{3}$ is launching a multimillion dollar public relations project, two main goals of which are:

- To convince the public that animal rightists are anti-science.

- To isolate the animal rights group from the general public.

The A.M.A. would be delighted with Sperling's characterization of us: anti-science cult.

Let me try to formulate the basic argument structuring Sperling's view. Apparently, cultural anthropology finds it important to study the symbolic roles of animals. Given that other sciences such as zoology, biology, ethology and psychology study the nature of animals, in and of themselves, it seems to be a fruitful study for anthropologists to study the human use of animals as representations of something else. This symbolic role of animals is prominent in what I take to be Sperling's basic argument:

\section{Interpretation of Sperling's Argument}

1. For you animal liberators, animals are a symbol for nature.

(Page 15: "Recently, animals have assumed a crucial symbolic role for many as representatives of a natural world....")

2. For you animal liberators, experiments on animals are a symbol for the scientific, technological manipulation and corruption of nature. (Page 155: Animal experimentation "is ... a perfect symbol for the modern dominance of technology over life.")

3. You animal liberators experience anxiety from the threat of, or actual, iechnological manipu- 
lation and corruption of nature.

(Page 28: "It is the linking of commonly felt anxieties and beliefs to the abuse of laboratory animals which gives the movement its distinctive and radical quality....")

4. Therefore, when you animal liberators protest animal experiments, you are not really protesting the harming of the animals. You are really protesting the anxiety caused in yourselves by the scientific, technological disruption of nature. (Page 132: "The roots of opposition to research with animals go far deeper than heightened humane responses to animal suffering.")

(Page 20: “... protest against research with animals ...is directed to concerns beyond the pain and suffering of animals.")

None of the statements in this argument reflect the essential nature of the animal rights movement. This analysis is wrong-headed. Why so? I will provide seven criticisms of Sperling's analysis, the first six mainly methodological, and the seventh-the most importantmore philosophical.

1. First, Sperling distorts the analysis by claiming that the animal rights movement has focused protest specifically on the use of animals by science, rather than on the general issue of humane treatment of animals in all contexts. "... The signal concern of the modern movement is experimentation" (p. 77). This is not true. A much larger percentage of Peter Singer's Animal Liberation ${ }^{4}$ (a book which Sperling acknowledges to be the "bible" of the movement) is on the topic of animals used for food, and vegetarianism, than on animal experimentation. The animal rights movement is protesting the harming of animals in all contexts. Henry Spira of New York, probably the best known and most effective animal rights activist in this country, has recently said: "We see the problem of farm animals as a top priority because $95 \%$ of all animal suffering in the U.S. is in factory farming." 5 By tagging animal experimentation as the central focus of the animal rights movement, Sperling distorts the nature of the movement.

2. Second, Sperling claims that an analysis of the 19th century British anti-vivisection movement is very helpful in understanding the modern movement. She is mistaken in this claim. The Victorian antivivisection movement had no intellectual foundation. Not a single British philosopher had any interest in the movement. Not a single sophisticated scientist participated in the movement. I spent one week in the British Museum Library analyzing the complete testimony presented before the 1876 Royal Commission on Vivisection. ${ }^{6}$ I made an analysis of the backgrounds of those who gave testimony. There were 49 representing science and medicine (including a very reluctant Charles Darwin). There were four on the anti-vivisection side, the main witness a courageous railroad engineer. The conflict between the scientific community and the Victorian anti-vivisectionists developed into a shouting match. The scientists were called "cruel monsters" and "murderers" and "torurers"; the anti-vivisectionists were called "antiscience," "fearing science," "ignorant of science," "irrational," "sentimental." The rhetoric on both sides was not impressive. Sperling's projection of Victorian anti-vivisectionist attitudes toward science on to the modern animal rights movement results in a major distortion. The fact that Victorian antivivisectionists paid little attention to vegetarianism should have alerted Sperling to fundamental differences between the two movements.

3. Third, Sperling's selection of animal rights literature is highly dubious. Her principal written sources for an analysis of the movement are flyers and pamphlets handed out at demonstrations against animal experiments, almost entirely, it appears, in the San Francisco Bay area. She finds 26 of these items to be "the richest source of written material on the developing ideology of the new groups" ( $p$. 97). In my recent Keyguide to Information Sources in Animal Rights ${ }^{7}$ I annotated 335 important works in the literature of the international animal rights movement. I should think these works would be a richer source than flyers and pamphlets. I provided information on 181 animal rights and animal welfare organizations, international and national. To restrict oneself to the ephemeral literature handed out by thirteen activist groups, most of them local, is inappropriate.

4. Fourth, Sperling's interviews with nine local animal rights activists do not significantly support her analysis of the movement. Sperling thinks it 
significant that most of these activists were also active in other movements, such as radical feminism, the ecological movement, holistic health, etc.; and she thinks this variety of simultaneous movement membership supports her thesis that the animal rightists are not protesting the harming of animals but are really protesting something else-the disruption of nature by modern technological science. I find a careful reading of the portions of the interviews quoted support more plausibly the view that the animal rights movement is essentially concerned with the harming of animals. And that the ecology movement is essentially concerned with the harming of both humans and animals through environmental damage. And that the feminists are essentially concerned with the harming of women as well as with the harming of animals. It should be no surprise that these movements interconnect. It is exactly what one would expect.

5. Fifth, it is surprising that Sperling, a scientist, does not pay more attention to the activities of scientists and scientific organizations within the movement. The enormously influential book Victims of Science, ${ }^{8}$ published in England in 1975, was by Richard Ryder. Ryder did animal research at Columbia University, has a degree in experimental psychology from Cambridge University, and has a diploma in clinical psychology from Edinburgh University. Donald Barnes, director of the Washington, D.C. branch of the National AntiVivisection Society ${ }^{9}$, is a psychologist who spent 15 years at the U.S. Air Force School of Aerospace Medicine, irradiating over 1,000 monkeys and baboons. Barnes changed his mind, breaking out of what he calls "conditioned ethical blindness," and became an activist. Sperling fails to consider three national scientific organizations in the United States:

- Psychologists for the Ethical Treatment of Animals ${ }^{10}$ with a board of directors including ten scientists with Ph.D.s. The executive director is Professor Kenneth Shapiro, Psychology Department, Bates College, Maine. The organization publishes important position papers and other material.

- The Association of Veterinarians for Animal Rights ${ }^{11}$ was founded in 1981 by Neil C. Wolff,
DVM, and Nedim C. Buyukmihci, VMD. Buyukmihci is a professor of opthalmology at University of California Davis, School of Veterinary Medicine. This organization has issued important position statements on twentyone animal rights topics.

- Physicians Committee for Responsible Medicine. ${ }^{12}$ This is a nation-wide group of physicians which supports students' rights to do no harm to animals. It has published important materials on alternatives to the use of animals in medical education. The chairman is Neal Barnard, M.D. from George Washington University School of Medicine, and a professor of psychiatry at that university.

It is unfortunate that Sperling relied heavily on flyers handed out at demonstrations, and paid little attention to these scientific organizations.

6. Sixth, it is astonishing that a book published in 1988 be so outdated. There is very little consideration of animal rights literature beyond 1984. In my research for the Keyguide to Information Sources in Animal Rights I soon realized we are in a virtual explosion of animal rights literature. I am convinced that more has been written on animals and ethics during the past 15 years than during all previous history. Approximately a third of the annotated works in my Keyguide were published after 1984.

7. My last and most important criticism is that Sperling ignores the essential nature of the animal rights movement. In her analysis, animals are symbols of something else; animal experiments are a symbol of something else. Very much to the contrary, the animal rights movement is concerned about the animals themselves - not about animals as symbols of something else. The movement is concerned about the harming of animals, not about the harming of animals as the symbol of something else. Let me give you the flavor of the major themes recurrent in the animal rights literature. It is not my intent to persuade; it is my objective to provide a framework by which you can appreciate the revolutionary nature of the animal rights position or positions. At the theoretical level there are some disagreements among animal rights philosophers. But amazingly, at the practical level, there is close agreement on how we ought to treat animals. 
I will consider six major themes in the animal rights literature:

\section{We humans are harming the animals.}

By the word "we" in this sentence, I mean we as a society, a society which institutionalizes the harming of animals. For example, although you and I are not now harmfully experimenting on an animal, we nevertheless are participating in animal experimentation by financing experiments through payment of taxes. Likewise, we are participating in the use of intensive factory farms in the raising of animals and poultry for food; we pay taxes to support land-grant universities which develop factory farming techniques.

Animal rightists are concemed about all types of harm to animals: in trapping, in hunting, in zoos, in animal experiments and testing, in rodeos, in circuses, in films, in raising and slaughtering animals for food, etc.

Peter Singer, in Animal Liberation, provides a detailed factual account of the various ways animals are harmed in animal laboratories and experiments and testing. Likewise, he gives an extensive factual description of how animals are harmed in intensive factory farming methods. Most readers of Animal Liberation are shocked to leam what is happening to animals. Sperling finds that readers of Singer's Animal Liberation experience something like a revelation. Sperling to the contrary, this is not something like a religious-cultish revelation; it is a factual revelation. My students in animal rights classes were stunned to learn what is happening to animals.

There are many ways in which we can harm animals:

1a. To destroy the matural habitat of an animal is to harm that animal.

Obviously, the very existence of an animal depends on its environment. This type of harm reveals the intimate connection between the animal rights movement and environmental and ecological movements.

1b. To remove an animal from its natural habitat is to harm that animal.

Removal from natural habitat results in extreme distress and terror, also in the disruption of psychological and social relations with other members of the species.

1c. To cause pain or distress or suffering or misery or terror in an animal, unless to

\section{benefit that animal, is to harm that} animal.

As for humans, there are situations where suffering is necessary for ultimate benefit. If I terrify a deer with a firecracker to scare it out of the hunter's range, the terror in this sense leads to the benefit of the deer.

1d. To mutilate an animal, unless to benefit that animal, is to harm the animal.

It is rather obvious that the removal of an animal's leg is not normally in that animal's interest. But if the leg is gangrenous, amputation may well benefit it.

1e. To kill an animal, unless to benefit that animal, is to harm the animal.

Some people seem to believe that if an animal be instantaneously killed, without any suffering, without any apprehension of being killed, the animal is not harmed. We surely do not think this when humans are killed instantaneously without suffering. Animal rightists regard killing as the ultimate harm, since it makes life impossible. There are cases where killing an animal is for its benefit; for example, when a deer is so severely mutilated when struck by a truck that it benefits the animal to be put out of its misery.

\section{The harming of an animal needs moral} justification.

We certainly believe that the harming of a human requires moral justification. Likewise, the harming of an animal needs moral justification.

3. The burden of providing a moral justification is on the person who harms an animal.

It is not the responsibility of the animal rightist to demonstrate that the harming of an animal is wrong. It is the responsibility of the harmer to demonstrate that the harming of an animal is not wrong.

Since Sperling analyzed the animal rights movement in terms of animal experimentation, let us take a look at typical attempts to justify harmful experiments on animals. Let me create a dialogue between the animal experimenter and the animal rightist.

Animal Experimenter: "Harmful experiments on animals are justified because God said it's O.K." 
Animal Rightist: "First, you will have to prove the existence of God, which is impossible. When and where did God say anything about animal experimentation? It is surprising that rational, empiricistic, objective scientists should turn to theology to try to justify their experiments." (Note: Perhaps you think my dialogue is exaggerated. In 1986, in an essay in the Annals of the New York Academy of Science ${ }^{13}$, psychology professor Neal Miller of Rockefeller University used the biblical situation of Abraham being told by God to spare Isaac and sacrifice a ram instead to try to show that animal suffering is to be chosen over human suffering. I trust Neal Miller is a better pyschologist than theologian. That certainly is not the point of the Abraham-Isaac episode.)

Animal Experimenter: "Harmful animal experiments are justified because society permits us to do it."

Animal Rightist: "Do you believe human slavery was justified because American colonial society permitted it? Do you believe the extermination of Jews at Dachau was justified because Nazi society permitted it?" (Note: Perhaps you think my dialogue is exaggerated. I debated with psychology professor Steven Suomi at the University of Wisconsin on his matemal deprivation experiments on monkeys. His only ethical justification was: society permits it.)

Animal Experimenter: "Harmful animal experiments are justified because we humans are rational and animals are not rational."

Animal Rightist: "Some animals are more rational than some humans. Chimpanzees are more rational than newly born human infants, and more rational than some severely retarded humans. Using this justification, you should experiment on some humans before experimenting on some animals. The use of rationality as a criterion is arbitrary. This kind of reasoning will lead you to the conclusion that it is much less objectionable to club a dull janitor than to club a smart college professor."

Animal Experimenter: "Harmful animal experimentation is justified because such experiments will give us knowledge about humans, which we can use to benefit us humans."

Animal Rightist: You can only obtain knowledge about humans in animal experimentation because of similarity between animals and humans. But surely humans are much more similar to humans, than they are to animals. So this is a still better reason for experiments on humans." (Note: R. G. Frey, a philosophy professor at Bowling Green State University who does not support moral rights for animals nevertheless concludes that we cannot justify harmful animal experiments on the basis of benefits without also justifying harmful experiments on humans. He concludes: "The case for antivivisectionism ... is far stronger than most people allow."14)

Animal Experimenter: "Harmful animal experimentation is justified because it will give us knowledge, and any kind of knowledge is good in and of itself, whether it helps humans or not."

Animal Rightist: "By that reasoning you must also conclude that experimenting on humans will give us knowledge, whether it helps humans or not."

The animal rights literature is rich in critical analyses of claimed justifications for harming animals - in all contexts, not only in animal experimentation. Animal rightists have come to the conclusion that no attempted justification will prove satisfactory and that we should radically change our views on, and treatment of, animals.

\section{We have a duty not to harm the animals.}

Let's take a brief look at how Peter Singer would interpret this claim. Peter Singer's theoretical framework is utilitarianism. According to utilitarianism the goal of all our actions and social policies should be to maximize the totality of pleasure-and-happiness and to minimize the totality of pain-and-suffering. Singer argues that equal pains and equal pleasures should be given equal consideration, regardless of species membership. A given quantity of pain or suffering in a horse should receive equal consideration, morally, as the same quantity of pain or suffering in George Bush. This is what Singer means when he refers to the moral equality of humans and animals. Anyone who denies the moral equality of humans and animals in this sense is regarded as a speciesist, analogous to sexism and racism. Apparently Singer would characterize Dr. Sperling as a speciesist. In the preface to her book she states "An education in evolution has left me with a strong conviction of human uniqueness, and I cannot view animals as moral equals." (p. xi) Sperling seems to be arguing that animals are not morally equal to 
humans because humans are unique. This is a very weak argument. One could just as well argue that humans are not morally equal to rats because rats are unique. Perhaps I do not understand what a species is. I am under the impression that all species are unique.

In his Animal Liberation Peter Singer argues that the totality of pain-and-suffering would be minimized, and the totality of pleasure-and-happiness would be maximized, by following a social policy of phasing out harmful animal experimentation and phasing out the use of animals for food.

Not all philosophers are in complete agreement with Peter Singer's theoretical framework. If I correctly understand Steve Sapontzis' theory, he argues for our duty not to harm animals on a somewhat expanded basis. ${ }^{15}$ His basic approach is that animal liberation can be based on three fundamental principles already well accepted in our moral tradition:

- We should be fair.

- We should minimize suffering and maximize happiness.

-We should develop moral character.

The application of these three principles will result in a close approximation to vegetarianism, with the conclusion that experiments on animals should be governed by the same moral principles which govern human experiments.

5. The animals have a right not to be harmed by us.

Some philosophers use rights language and argue that a rights view is still stronger than a duty view as expressed in (4) above. Tom Regan, North Carolina State University, is the most prominent theorist arguing for animal rights in a technical sense. ${ }^{16}$ Using principles of justice and equality, Regan develops a theory of moral rights for humans and animals, based on the equal inherent value of individuals which have experiences, individuals which are subjects of a life, individuals whose lives can become better or worse for them. Regan emphasizes the right not to be harmed, arguing the infliction of death to be the ultimate harm. Regan concludes: vegetarianism is morally obligatory; hunting and trapping are morally wrong; and harmful experiments and tests on animals should cease.

\section{Therefore, we should stop harming animals.}

This final conclusion reveals the revolutionary nature of the animal rights movement. This is not an absolute claim; it is a prima facie obligation which holds except in extraordinary situations. The prima facie principle we should not harm humans generally applies; but the right of self-defense may justify exceptions. Similarly, our obligation not to harm animals may sometimes be weaker than our right to defend ourselves against threatened or actual harm by animals. Sperling, in her Animal Liberators, ignores the revolutionary nature of the animal rights movement. Traditionally, animals have been regarded as resources to serve human interests. This tradition has one imperative: when harming animals to serve human interests do not cause unnecessary harm. That is, do not cause the animal any more harm than is required to serve the human interest. On the contrary, the animal rights movement stresses the revolutionary imperative: Do not harm animals. Period. Animals are not resources for human manipulation. The same basic moral principles apply to humans and animals.

Experiments on animals should be governed by the same ethical guidelines as those applying to experiments on humans. The same Institutional Review Board should be the approving agency for both human experiments and animal experiments. Risks (physical, psychological and social) to the animal should be carefully analyzed. The interests and the well being of the animal should be protected. Informed consent should be obtained. Three underlying ethical principles should be followed: the respect principle, the beneficence principle, and the justice principle.

Someone may object: "But animals cannot give informed consent!" What follows from this objection? The conclusion that we can therefore experiment on animals? From the fact that human infants cannot give informed consent it does not follow that we are free to experiment on them. Animals have some ability to express their willingness or unwillingness to participate in experiments. ${ }^{17}$ Their body language is communicative. They can "vote with their feet." To the extent that animals cannot express consent or dissent, guardians or special advocates should be appointed to protect the animals' interests. Animals should be classified as "vulnerables," as are human infants and the severely retarded.

Animal rightists are not anti-science. Animal rightists are against harming animals in all contexts. The application of ethical guidelines to animal experiments is no more anti-science than the application of the same guidelines to human experiments. 


\section{Notes}

1 United States Department of Health, Education and Welfare (DHEW), "Protection of Human Subjects," 45 CFR 46, 39 Federal Register 18917, May 30, 1974. The National Research Act of 1974 established a National Commission for the Protection of Human Subjects and Behavioral Research.

2 United States. Department of Health, Education and Welfare, "The Belmont Report: Ethical Principles and Guidelines for the Protection of Human Subjects of Reseanch." The National Commission for the Protection of Human Subjects of Biomedical and Behavioral Research, DHEW Publication No. (OS) 78-0012, U.S. Government Printing Office, 1978, pp. 4-20.

3 "AMA Animal Research Action Plan," June, 1989, $12 \mathrm{pp}$. I do not know whether this action plan has been published. A copy has been circulated within the animal rights movement.

${ }^{4}$ Animal Liberation: A New Ethic for Our Treatment of Animals (New York: Avon Books, 1975, 297 pp.)

5 Quoted in "Out of the Cage: The Movement in Transition," by Merritt Clifton in The Animals' Agenda, January/February 1990, pp. 26-30. This five page report, based heavily on the outside perspective of Social Movement Empowerment Project analyst Bill Moyer, provides a much better understanding of the animal rights movement than does Sperling's book. Moyer analyzes social change movements into eight stages; he concludes that the animal rights movement is now leaping from stage four to stage six. "Stage four comes as catalytic events bring the cause to public consciousness, and turn opinion in favor of the movement. New organizations spring up, mass marches and demonstrtions are staged, and the status quo launches a counteroffensive." "During stage six a new social and political consensus grows that erodes the powerholders' ability to continue their policies."

${ }^{6}$ Great Britain. Report of the Royal Commission on the Practice of Subjecting Live Animals to Experiments for Scientific Purposes. Command 1397 and 1864. 1876-1877. London: HMSO.

${ }^{7}$ Mansell Publishing Limited, London, and McFarland and Company Publishers, Jefferson, North Carolina, 1989, $267 \mathrm{pp}$.

8 Victims of Science: The Use of Animals in Research. (London: Davis-Poynter, 1975, 279 pp.) Revised edition: (London: National Anti-Vivisection Society, 1983, 190 pp.)

${ }^{9} 112$ North Carolina Avenue SE, Washington, D.C. 20003.
10 c/o Psychology Department, Bates College, Lewiston, ME 04240.

11530 East Pumam Avenue, Greenwich, CT 06830.

12 P.O. Box 6322, Washington, D.C. 20015.

13 'The Morality and Humaneness of Animal Research on Stress and Pain," Annals of the New York Academy of Sciences 1986, 467: 402-4.

14 R. G. Frey, Rights, Killing, and Suffering. (Oxford: Basil Blackwell, 1983) pp. 111-116.

15 Steve F. Sapontzis, Morals, Reason, and Animals. (Philadelphia: Temple University Press, 1987)

${ }^{16}$ Tom Regan, The Case for Animal Rights. (Berkeley: University of California Press, 1983)

${ }^{17}$ Steve Sapontzis: “... To claim that animals can give or withhold consent to participate in an experiment is not absurd. On the contrary, it is something animals commonly do, something that is easily recognized, and something that is often properly informed and reasonable, from the animals' point of view ...." Morals, Reason, and Animals, p. 213.

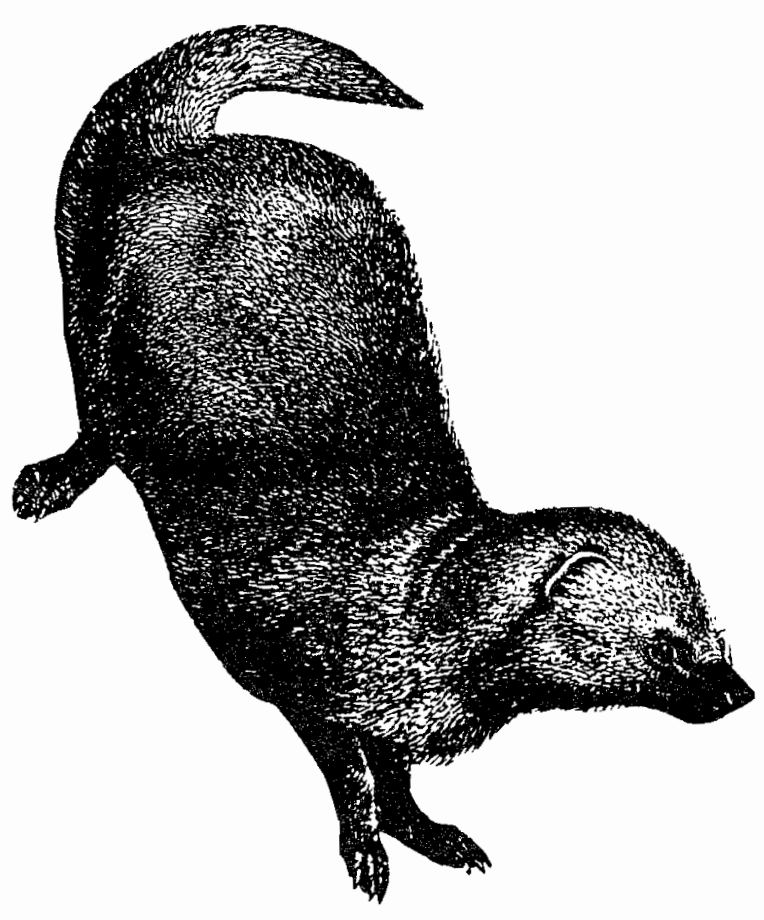

